\title{
NUTRIVIGILANCE: A NEW ACTIVITY IN THE FIELD OF DIETARY SUPPLEMENTS
}

\author{
CLAUDIU MORGOVAN ${ }^{1,2 \#}$, STELIANA GHIBU ${ }^{3 *}$, ANCA MARIA JUNCAN $^{2 \#}$, LUCA LIVIU $^{2}$ \\ RUS $^{2 \#}$, ANCA BUTUCA ${ }^{2}$, LOREDANA VONICA ${ }^{2}$, ANDREI MUNTEAN ${ }^{2}$, LIANA MO $^{4}$, \\ FELICIA GLIGOR ${ }^{2}$, NELI-KINGA OLAH ${ }^{1}$ \\ 1 "Vasile Goldiș” Western University, Faculty of Pharmacy, 86 Liviu Rebreanu Street, Arad, Romania \\ 2 "Lucian Blaga” University, Faculty of Medicine, Preclinical Department, 2 A Lucian Blaga Street, Sibiu, Romania \\ 3 "Iuliu Hatieganu” University of Medicine and Pharmacy, Faculty of Pharmacy, Department of Pharmacology, Physiology \\ and Pathophysiology, 8 Victor Babeș Street, Cluj-Napoca, Romania \\ 4 “Vasile Goldiş" Western University, Faculty of Medicine, 86 Liviu Rebreanu Street, Arad, Romania
}

*corresponding author: stelianaghibu@yahoo.com

\#Authors with equal contributions

Manuscript received: October 2018

\begin{abstract}
Dietary supplements (DS) used to improve the quality of life, can produce adverse events, either as a result of inappropriate consumption, or as the intrinsic properties of active compounds, either as drug-dietary supplement interactions or due to contaminations or adulterations. The European legislation, including the Romanian legislation doesn't refer to all types of DS, and even more it doesn't contain any regulations regarding detecting, monitoring or reporting adverse events. In the last years, some countries (USA, France, Czech Republic) started the nutrivigilance, a scientific support in order to identify the possible adverse effects of DS and to enhance consumer safety, necessary for detection, understanding and prevention of adverse events related to the use of DS, a major public health risk, which can lead to an inappropriate practice and may eventually be harmful to patients' lives. This study highlights the necessity to introduce the nutrivigilance as a habitual practice and activity of all authorities and actors from the Romanian dietary supplements' market, due the increase of dietary supplements consumption and their risks for the people's health.
\end{abstract}

\section{Rezumat}

Utilizate cu scopul de a creşte calitatea vieţii, suplimentele alimentare pot cauza reacţii adverse, fie ca urmare a consumului inadecvat sau din cauza proprietăţilor intrinseci ale compuşilor activi conţinuţi, fie datorită interacţiunilor medicament - supliment alimentar, sau chiar a contaminării sau falsificării lor. Legislaţia europeană, inclusiv cea românească, nu reglementează toate categoriile de suplimente, şi cu atât mai mult nu conţine aspecte privind detectarea, monitorizarea şi raportarea reacțiilor adverse cauzate de acestea. In ultimii ani, câteva state (SUA, Franţa, Cehia etc.) au introdus nutrivigilenţa, o nouă ştiinţă şi activitate necesară pentru detectarea, evaluarea, înţelegerea şi prevenirea efectelor adverse produse de suplimentele alimentare. Lucrarea de faţă doreşte să evidenţieze necesitatea introducerii nutrivigilenţei ca o practică şi activitate permanentă a tuturor autorităţilor şi actorilor implicaţi în piaţa suplimentelor alimentare din România, ca urmare a tendinţei de creştere accelerată a consumului acestora, dar şi a riscurilor pe care aceste produse le pot avea pentru sănătatea populaţiei.

Keywords: nutrivigilance, dietary supplements, adverse events, legislation and regulations

\section{Introduction}

Nowadays, the modern human being has new standards regarding their personal life, like having good health status or increasing their quality of life. The daily stress, food habits, sedentary lifestyle and the pollution are the main factors which can lead to a suboptimal state of health. This can be attenuated or reduced by the use of dietary supplements (DS) [10, 60]. The demand for these products shows an increasing trend all over the world. The DS market makes a fast development, so, drugs manufacturers identified a good opportunity for their business, in this segment. The increasing prevalence of different pathologies such as cardiovascular diseases, cancers, diabetes, epilepsy, respiratory or digestive disease etc. [20, 34, $36,62]$ determined people to use more and more natural products as adjuvant therapy, or for prevention or correction of some biological imbalances. In some cases, the DS can partially replace the high amount of prescribed drugs (non-steroidal anti-inflammatory drugs, antihypertensive drugs, statins, oral antidiabetics, gastrointestinal agents etc.) [1, 5, 6, 22, 59], for limiting the risks of drugs adverse reactions. Today, when the pharmaceutical market registers a lot of tensions, the development of the health products trade (drugs, DS, cosmetics, medical devices etc.) is a good opportunity to improve the economic efficacy of the pharmacies. Thus, this business determines an 
increase in the turnover, in the net profit and also in the cash flow obtained by pharmacies [35].

\section{Materials and Methods}

In this study there were analysed the main regulations about DS from European Union (EU) and Romania: a) Directive 2002/46 EC; b) Regulation (EU) no. 432/2012; c) Law 491/2003 republished in 2011; d) Joint Order no. 244/401/2005 of Ministry of Agriculture, Forests and Rural Development and Ministry of Health; e) Joint Order no. 1228/2005/ $63 / 244 / 2006$ of the Ministry of Agriculture, President of the National Sanitary Veterinary and Food Safety Authority and Ministry of Health; f) Order no. 1069/ 2007 of the Ministry of Health; g) Order no. 1946/ 2014 of Ministry of Agricultures and Rural Development $[15,30,40-43,48]$. This research has been carried out employing the comparative method and interpretation method $[9,10]$ of the regulations from this field.

\section{Results and Discussion}

Regulations regarding the dietary-supplement activity The first regulation regarding DS was introduced in 1994, in the US. In this regard, the "Dietary Supplement Health and Education Act of 1994" stipulates that DS are foodstuffs, not drugs [57]. Following this regulation, the EU authorities have tried to implement some rules for the DS field. Despite all EU Commission's and the professionals' efforts from over the last 25 years, the field of dietary supplements is not yet entirely covered by a unitary legislation to this day. In this regard, the Directive 2002/46/EC, approximates the laws of the Member States relating to DS. According to this Directive, the dietary supplements mean foodstuffs used to supplement the normal diet. Moreover, DS "are concentrated sources of nutrients or other substances with a nutritional or physiological effect, alone or in combination, marketed in dose forms", meaning capsules, pastilles, tablets, pills and other similar forms, sachets with powder, ampoules with liquids, drops in dispensing bottles, and other similar forms of liquids and powders designed to be taken in measured small-unit quantities [15]. The DS contain a wide range of nutrients or other ingredients: vitamins, minerals, amino acids, enzymes, essential fatty acids, prebiotics, probiotics, botanicals and botanical extracts, as: Q10 coenzyme, lycopene, inositol, glucosamine, spirulina etc. $[15,18]$.

These products started to gain market share in the EU over the last twenty years, after the recognition of their nutritional role [18]. At the moment, there is a unitary EU legislation regarding the DS with vitamins and minerals. This establishes: 1) the vitamins and minerals that can be used as DS and their maximal quantities; 2) the wording of health-related claims that can be written on the packages respectively; 3 ) the products' authorization procedure by a notification $[15,16,47]$. It should be mentioned that even if DS are foodstuffs, the specific legislation regarding the food labelling or advertising [46] doesn't refer entirely to DS. The EU authorities launched a process evaluation of all possible foodstuffs components, in order to establish which kind of health-related claims can be approved to be written on the products' labels. The result of this process was the issue of a new EU Regulation (432/2012) that established the wording of the health claims for all vitamins and minerals and respectively for a few other usual nutrients [48]. At the same time, this process has shown how difficult it is to evaluate the botanicals, from the same point of view as the vitamins and minerals. However, we are still missing a unitary legislation or requirements for botanical-origin DS.

At the moment, in Romania, the specific legislation of DS includes many normative acts (Table I). Thus, the legislative aspects referring to DS from medicinal plants and hive products was regulated through the republished Law no. 491/2003 [30] and through the Joint Order of Ministry of Agriculture, Forests and Rural Development and Ministry of Health no. 244/ 401 from 2005 [40]. The Joint Order no. 1228/2005/ $63 / 244 / 2006$ contains regulations regarding the DS of animal, plant origin and/or their mixtures with vitamins, minerals or other nutritive substances. In this Order, there are established: 1) the DS categories; 2 ) the authorization procedure; 3 ) the labelling and advertising rules adopted from the foods legislation which shouldn't overlap with regulations of drugs $[10,41]$. The legislation regarding DS with minerals and/or vitamins was adopted in Romania by the Health Minister's Order no. 1069 from 2007. The Romanian legislation also specifies that a DS is a product which supplements the normal diet, taken orally by a healthy person which needs an increase in nutrients exogenous intake [42].

In the last few years it was introduced the term of "novel food" to cover the possibility of introducing new food ingredients that are not recognized at this moment as foodstuffs. The new EU and Romanian regulations in this field has the aim to request from the manufacturers more proofs regarding the safety and efficacy of these kind of food ingredients before they are introduced in usual foods or are marketed as they are [26].

The Romanian DS legislation respects two essential principles: 1) the consumer has not been misled or exposed to aggressive trade techniques; 2) any affirmation must be clear, exact and justified, and must allow the consumer to choose the desired and appropriate product $[10,37,40-43]$. The DS label is not mandatory to contain information referring to the prevention, treatment or cure of any pathology $[42,43]$. 
Romanian legal background for dietary supplements

\begin{tabular}{|c|c|c|}
\hline Regulatory approach & Year & Description \\
\hline Law no. $491[30]$ & $\begin{array}{l}2003 \\
\text { (republished } \\
\text { in 2011) }\end{array}$ & $\begin{array}{l}\text { - } \quad \text { rules for manufacturing of medicinal plants and hive products } \\
\text { - medicinal plants or hive products must be notified at the Institute for } \\
\text { Food Bio-Resources Bucharest or at Regional Centre of Public Health } \\
\text { from Cluj-Napoca, Iaşi or Timişoara }\end{array}$ \\
\hline $\begin{array}{l}\text { Joint Order of Ministry of } \\
\text { Agriculture, Forests and Rural } \\
\text { Development and Ministry of } \\
\text { Health no. 401/244 [40] }\end{array}$ & 2005 & $\begin{array}{ll} & \text { list of botanicals that can be used in DS } \\
\text { - } & \text { list of herbs and plants prohibited to use in DS } \\
\text { - } & \text { list of cultivated and wild mushrooms that can be used in DS }\end{array}$ \\
\hline $\begin{array}{l}\text { Joint Order no. } 1228 / 63 / 244 \text { of } \\
\text { the Ministry of Agriculture, } \\
\text { President of the National } \\
\text { Sanitary Veterinary and Food } \\
\text { Safety Authority and Ministry } \\
\text { of Health [41] }\end{array}$ & 2005 & $\begin{array}{l}\text { - trade in DS which contain animal or herbal products (extracts) or in } \\
\text { combination with vitamins and minerals } \\
\text { - } \\
\text { dosage forms of DS and authorization, packing, labelling and advertising } \\
\text { rules } \\
\text { - } \\
\text { the animal or herbal DS must be notified at the Institute for Food Bio- } \\
\text { Resources Bucharest or at the Regional Centre of Public Health from } \\
\text { Cluj-Napoca, Iaşi or Timişoara }\end{array}$ \\
\hline $\begin{array}{l}\text { Order of Ministry of Health } \\
\text { no. } 1069[42]\end{array}$ & 2007 & $\begin{array}{l}\text { - } \quad \text { notification of DS consisting exclusively of nutrients (such as vitamins } \\
\text { and minerals), such nutrients being synthetically obtained. } \\
\text { - } \quad \text { rules regarding DS authorization, packing, labelling and advertising } \\
\text { - } \quad \text { DS (exclusively vitamins or minerals) must be notified at the Ministry of } \\
\text { Health }\end{array}$ \\
\hline $\begin{array}{l}\text { Order of Ministry of } \\
\text { Agricultures and Rural } \\
\text { Development no. } 1946[43]\end{array}$ & 2014 & $\begin{array}{l}\text { - the notification procedure of DS which contain animal or herbal } \\
\text { products (extracts), or in combination with vitamins and minerals } \\
\text { (including external products, hive products, cosmetics etc.) } \\
\text { - } \quad \text { the content of the safety report on DS }\end{array}$ \\
\hline $\begin{array}{l}\text { Government Decision no. } 590 \\
\text { [26] }\end{array}$ & 2018 & $\begin{array}{l}\text { - the procedural steps of the consultation process for establishing the status } \\
\text { of novel food }\end{array}$ \\
\hline
\end{tabular}

According to Order no. 1946/2014 the notification file has to contain a Product Safety Report filled by a qualified person in pharmacy, toxicology, medicine or other related field [43]. Even if DS are not drugs, the Romanian regulations allow the writing of short health claims on products, but there is no regulation to force manufacturers to demonstrate the efficacy of DS, claimed on the labels or leaflets. As a result, due to the lax manner of notification on these products, their efficacy and safety are exclusively the producers' responsibility. There are some situations, when the inefficient, low-quality or unsafe (counterfeited or contaminated) products appeared on the market. Also, in Romania, several instances in which DS advertising was misleading have been identified [10]. The evolution of dietary supplements market

The request for DS has been registering a significant growth during the last years, which determined more and more producers to enter in this segment. The results of different studies have shown a continuous increasing of the number of healthcare products such as drugs, DS, medical devices, cosmetics etc., on the pharmaceutical market [11, 18, 19, 28, 35]. The magazine articles, TV shows, advertising, online forums, blogs or websites, celebrities etc., all offer information about DS. All these media increase the credibility of DS, about their role in the preventive or curative healthcare and also the DS consumption [56].
In 2012, the worldwide market was valued at $\$ 82$ billion (US $\sim 28 \%$, Europe $\sim 10 \%$ ). It was estimated that the annual growth would be $5-6 \%$ [56]. In the US, there are more than 85,000 products with vitamins, minerals, botanicals, amino acids, probiotics etc. [8]. In 2013, in US, vitamins (32.2\%) and botanicals $(17.1 \%)$ were the best-selling DS [19]. More than 36\% American DS consumers were over 65 years old [56].

In 2015, the value of DS market in Europe was over 7.1 billion euros, and in 2020, it is projected to grow by around $9.5 \%$ (at 7.9 billion euros). Following the international trend, the DS Romanian market has been developing over the past years (72.2 million euros, in 2015). The Eastern European countries are projected to be the top fastest-growing markets: Romania (+41\%), Turkey $(+27 \%)$, Bosnia-Herzegovina $(+23 \%)$, Russia $(+21.5 \%)$ and Macedonia (+19\%) [64]. Thus, the Romania represents the most attractive market, with the greatest potential. Several factors are contributing to this evolution. For example, the people's attitude towards adopting a healthy lifestyle has improved due to the increase in the level of education and degree of information. Other causes are the developing of distribution channels and the expansion of DS advertising [10, 56, 60]. The DS can be procured from pharmacies, drugstores, supermarkets, specialized shops, the Internet, independent sellers etc. In this context, the pharmacies role in the 
DS providing is reduced, although the pharmacists have the competences to offer appropriate information. Thus, a study carried out in the US showed that in 2012 only about $18 \%$ of DS were sold in pharmacies, while the rest was sold by supermarkets or hypermarkets, specialized retailers, direct selling, Internet or home-selling [56], possibly due to their easy affordability.

Dietary supplements and adverse events

As it was presented above, DS can be purchased from different unspecialized places including the Internet which represents a comfortable source. Unfortunately, the lack of correct medical information or scientific support for these online-purchased products represents a major public health risk, which can lead to an inappropriate practice and may eventually be harmful to patients' lives. The main problems of DS intake are represented by several adverse events (e.g.: hepatic, cardiac, renal, metabolic disorders, neurotoxicity, teratogenicity etc.). An adverse event is defined as "any health-related event associated with the use of a dietary supplement that is adverse" [51]. The adverse event can be determined by: a) the intrinsic adverse effects of DS induced by the active substances or b) the interactions between dietary supplements and drugs (Table II).

Other adverse events of DS can be determined by the adulteration to improving their activity (e.g.: improve the sexual activity, reduce the articular or neck pain, lose body weight, improve the athletic performances etc.) with pharmacological active substances such as steroids, antidepressants, neurostimulants (sibutramine, a methamphetamine analogue), phenolphthalein, sildenafil analogues etc. [8, 21, 32, 52]. On the other hand, the involuntary or incorrect administration of some DS which contain prohibited substances (with stimulant, doping effects etc.) may cause disqualification of the athletes from various competitions [32]. For example, three athletes were disqualified from the 2014 Winter Olympic Games because they used DS contaminated with 1,3-dimethylamylamin - a sympathomimetic substance withdrawn from the market in 1983 [8]. Although the DS are efficient and easily affordable, they can have negative consequences on health, as it was mentioned above. Because of this, it is necessary to implement a system to prevent and monitore the adverse events of DS.

Table II

Adverse effects and drug interactions of some dietary supplement

\begin{tabular}{|c|c|c|c|}
\hline $\begin{array}{c}\text { Substance } \\
\text { Medicinal plant }\end{array}$ & Current use & Adverse event & Interactions with drugs \\
\hline $\begin{array}{l}\text { Aloe vera } \\
{[1,7,33]}\end{array}$ & $\begin{array}{l}\text { immunomodulatory, } \\
\text { antioxidant, } \\
\text { antibacterial, laxative }\end{array}$ & $\begin{array}{l}\text { gastrointestinal complaints, } \\
\text { arrhythmias, nephropathies, } \\
\text { oedema }\end{array}$ & + antidiabetics $\rightarrow$ hypoglycaemia \\
\hline $\begin{array}{l}\text { Aristolochic acids } \\
\text { Aristolochia sp. } \\
{[25,52,53]}\end{array}$ & $\begin{array}{l}\text { joint pain, stomach ache, } \\
\text { malaria }\end{array}$ & Nephropathy & \\
\hline $\begin{array}{l}\text { Chelidonium majus } \\
{[21,54,63]}\end{array}$ & $\begin{array}{l}\text { dyspepsia, irritable bowel } \\
\text { syndrome }\end{array}$ & Hepatitis & + hormones, anti-inflammatories \\
\hline $\begin{array}{l}\text { Citrus sp. } \\
{[7,14,38]}\end{array}$ & $\begin{array}{c}\text { antioxidant, } \\
\text { anti-tumoural, } \\
\text { anti-inflammatory, anti- } \\
\text { atherosclerotic, } \\
\text { natural preservative }\end{array}$ & Hyperacidity & $\begin{array}{l}\text { enzyme inhibitor, acting on CYP3A4 and } \\
\text { P-glycoprotein } \\
\text { Interacts with calcium channel blockers, } \\
\text { sedatives etc. } \\
\text { Inhibits the intestinal organic anion } \\
\text { transporting polypeptides (OATPs) that } \\
\text { facilitate the drugs absorption }\end{array}$ \\
\hline $\begin{array}{l}\text { Cytisus sp. } \\
{[21,63]}\end{array}$ & $\begin{array}{l}\text { antioxidant, diuretic, } \\
\text { anxiolytic, antidiabetic, } \\
\text { antiparasitic }\end{array}$ & $\begin{array}{l}\text { dizziness, headache, } \\
\text { heartbeat changes, leg } \\
\text { weakness, sweating, } \\
\text { sleepiness, mydriasis }\end{array}$ & \\
\hline $\begin{array}{l}\text { Echinacea purpurea } \\
\quad[1,13,24,31]\end{array}$ & $\begin{array}{l}\text { antioxidant, immunostimulant, } \\
\text { anti-inflamatory, anti- } \\
\text { bacterial, antifungal, antiviral }\end{array}$ & rash, headache, drowsiness & $\begin{array}{c}+ \text { lorazepam, pantoprazole } \rightarrow \\
\text { hallucinations }\end{array}$ \\
\hline $\begin{array}{c}\text { Ginkgo biloba } \\
{[1,3,12,24,58]}\end{array}$ & $\begin{array}{l}\text { ischemic protective } \\
\text { antioxidant }\end{array}$ & $\begin{array}{l}\text { gastrointestinal complaints, } \\
\text { allergic reactions, } \\
\text { hypotension }\end{array}$ & $\begin{array}{c}+ \text { amitriptyline, and acetaminophen-- } \\
\text { hydrocodone } \rightarrow \text { seizure } \\
+ \text { warfarin use } \rightarrow \text { increased risk of bleeding }\end{array}$ \\
\hline $\begin{array}{l}\text { Green tea extract } \\
\text { Camellia sinensis } \\
{[4,7,38,45,54]}\end{array}$ & body weight loss & liver injury & $\begin{array}{c}+ \text { warfarin, anti-hypertensives } \rightarrow \text { reduces } \\
\text { drug effects }\end{array}$ \\
\hline $\begin{array}{l}\text { Hypericin } \\
\text { St. John's wort } \\
\quad \text { Hypericum } \\
\text { perforatum } \\
{[1,3,7,12,13,29,58]}\end{array}$ & antidepressant, anxiolytic & $\begin{array}{l}\text { diarrhoea, vomiting, } \\
\text { drowsiness, agitation, rash, } \\
\text { photosensitization }\end{array}$ & $\begin{array}{l}\text { + oral contraceptives, warfarin, omeprazole, } \\
\text { amiodarone, carbamazepine, alprazolam } \rightarrow \\
\text { reduces the clinical efficiency of drugs } \\
+ \text { fluoxetine, paroxetine, sertraline, } \\
\quad \text { triptans } \rightarrow \text { serotonin syndrome }\end{array}$ \\
\hline
\end{tabular}


FARMACIA, 2019, Vol. 67, 3

\begin{tabular}{|c|c|c|c|}
\hline $\begin{array}{c}\text { Substance } \\
\text { Medicinal plant }\end{array}$ & Current use & Adverse event & Interactions with drugs \\
\hline $\begin{array}{c}\text { Kava extract } \\
\text { Piper methysticum } \\
{[3,7,13,24,29]}\end{array}$ & anxiolytic & $\begin{array}{c}\text { hepatitis, headache, nausea, } \\
\text { drowsiness, dyspnoea, } \\
\text { pruritus }\end{array}$ & $\begin{array}{l}+ \text { alprazolam } \rightarrow \text { increases drug effect } \\
+ \text { levodopa } \rightarrow \text { decreases drug effect }\end{array}$ \\
\hline $\begin{array}{l}\text { Lamiaceae sp. With } \\
\text { high contents in } \\
\text { rosmarinic acid } \\
{[21,39]}\end{array}$ & $\begin{array}{l}\text { Antioxidant, } \\
\text { hepatoprotective, } \\
\text { antibacterial }\end{array}$ & Hypertension & $\begin{array}{l}\text { inhibits the organic anions transporters } \\
\text { SLC22A6 and SLC22A8, inhibiting } \\
\text { some drugs absorption }\end{array}$ \\
\hline $\begin{array}{c}\text { Milk thistle } \\
\text { Silybum marianum } \\
{[3,21,55]}\end{array}$ & $\begin{array}{l}\text { hepatoprotection } \\
\text { protein synthesis }\end{array}$ & $\begin{array}{l}\text { headache, dizziness, } \\
\text { pruritus, laxative effect }\end{array}$ & $\begin{array}{c}+ \text { antiretrovirals, warfarin, diazepam } \rightarrow \\
\text { decreases drug effect }\end{array}$ \\
\hline $\begin{array}{l}\text { Passiflora incarnate } \\
{[7,21]}\end{array}$ & $\begin{array}{l}\text { anxiolytic, } \\
\text { antihypertensive }\end{array}$ & $\begin{array}{l}\text { dizziness, confusion } \\
\text { drowsiness }\end{array}$ & $\begin{array}{c}+ \text { warfarin, antiepileptics } \rightarrow \text { increases } \\
\text { drug effect }\end{array}$ \\
\hline $\begin{array}{l}\text { Saw palmetto extract } \\
\text { Seronoa repens } \\
{[7,8,13,24]}\end{array}$ & $\begin{array}{l}\text { used in benign prostatic } \\
\text { hyperplasia }\end{array}$ & $\begin{array}{l}\text { pruritus, tingling of } \\
\text { extremities, nausea } \\
\text { dizziness, vomiting }\end{array}$ & $\begin{array}{l}+ \text { hormone therapy } \rightarrow \text { decreases drug } \\
\text { effect }\end{array}$ \\
\hline $\begin{array}{c}\text { Senna } \\
\text { Cassia angustifolia } \\
{[21,54]}\end{array}$ & laxative & hepatitis & $\begin{array}{c}+ \text { digitalis glycosides } \rightarrow \text { increases } \\
\text { digitalis toxicity } \\
+ \text { antiarrhythmic } \rightarrow \text { arrhythmias } \\
+ \text { indomethacin } \rightarrow \text { decreases the } \\
\text { therapeutic effect of Senna }\end{array}$ \\
\hline $\begin{array}{c}\text { Usnic acid } \\
\text { (a secondary lichen } \\
\text { metabolite) }[4,54]\end{array}$ & antimicrobial & $\begin{array}{l}\text { local irritation, } \\
\text { contact dermatitis, } \\
\text { liver injury }\end{array}$ & + rifampicin $\rightarrow$ increase drug effect \\
\hline $\begin{array}{l}\text { Valeriana officinalis } \\
\quad[7,13,29]\end{array}$ & anxiolytic-sedative-hypnotic & $\begin{array}{l}\text { vomiting, nausea, agitation, } \\
\text { dizziness, drowsiness, } \\
\text { headache }\end{array}$ & $\begin{array}{c}+ \text { antiepileptics, barbiturates } \rightarrow \text { increases } \\
\text { drug effect }\end{array}$ \\
\hline Creatine [13] & $\begin{array}{l}\text { metabolism of skeletal } \\
\text { muscle }\end{array}$ & $\begin{array}{c}\text { proteinuria, agitation, } \\
\text { vomiting }\end{array}$ & + glucose $\rightarrow$ increase total muscle mass \\
\hline $\begin{array}{l}\text { Lysine (partial 5HT4 } \\
\text { receptor antagonist) } \\
\text { [49] }\end{array}$ & anxiolytic & diarrhoea, abdominal pain & \\
\hline $\begin{array}{l}\text { Omega-3 fatty acids } \\
\text { (fish oil, linseed) } \\
{[6,12,29]}\end{array}$ & $\begin{array}{l}\text { prevention of cardio- } \\
\text { vascular diseases, } \\
\text { reduces the production of } \\
\text { PGE }_{2}, \\
\text { antidepressant }\end{array}$ & $\begin{array}{c}\text { gastrointestinal reactions, } \\
\text { dysgeusia }\end{array}$ & $\begin{array}{l}+ \text { anticoagulants } \rightarrow \text { bleeding, bruising } \\
+ \text { antidepressant } \rightarrow \text { increases drugs effect }\end{array}$ \\
\hline $\begin{array}{l}\text { Melatonin } \\
{[7,23,29]}\end{array}$ & $\begin{array}{l}\text { regulates the circadian } \\
\text { rhythm }\end{array}$ & nausea, headache, dizziness & $\begin{array}{c}+ \text { antidepressants } \rightarrow \text { decreases drug } \\
\text { effect }\end{array}$ \\
\hline $\begin{array}{l}\text { Magnesium } \\
{[7,17]}\end{array}$ & $\begin{array}{l}\text { anxiolytic, involves in } \\
\text { metabolic reactions }\end{array}$ & $\begin{array}{l}\text { abdominal pain, } \\
\text { diarrhoea }\end{array}$ & $\begin{array}{l}+ \text { quinolones, tetracycline, nitrofurantoin } \\
\rightarrow \text { decreased antibiotic absorption. }\end{array}$ \\
\hline $\begin{array}{c}\text { Zinc } \\
{[13,29]}\end{array}$ & $\begin{array}{l}\text { relieves symptoms of } \\
\text { common colds, } \\
\text { CNS functioning }\end{array}$ & $\begin{array}{l}\text { nausea, vomiting, metallic } \\
\text { taste, sideroblastic anaemia }\end{array}$ & $\begin{array}{c}+ \text { quinolones, tetracycline } \rightarrow \text { decreased } \\
\text { antibiotic absorption. }\end{array}$ \\
\hline $\begin{array}{c}\text { Vitamin D3 and } \\
\text { calcium phosphate } \\
{[50]}\end{array}$ & bone metabolism & $\begin{array}{l}\text { constipating, bloating, } \\
\text { metallic taste, thirst, } \\
\text { tiredness, weakness, loss of } \\
\text { appetite, muscle pain }\end{array}$ & $\begin{array}{l}\mathrm{Ca}^{2+}+\text { quinolones, tetracycline } \rightarrow \\
\text { decreased antibiotic absorption }\end{array}$ \\
\hline $\begin{array}{l}\text { Vitamin C } \\
{[6,49,58]}\end{array}$ & antioxidant & $\begin{array}{l}\text { nausea, pyrosis, diarrhoea, } \\
\text { renal calculi }\end{array}$ & $\begin{array}{c}+ \text { co-trimoxazole } \rightarrow \text { increases drug } \\
\text { absorption }\end{array}$ \\
\hline $\begin{array}{l}\text { Vitamin A } \\
{[7,49]}\end{array}$ & $\begin{array}{l}\text { well-functioning of skin } \\
\text { antioxidant }\end{array}$ & $\begin{array}{l}\text { general weakness, dizziness, } \\
\text { headache, intracranial } \\
\text { pressure, nausea, vomiting }\end{array}$ & $\begin{array}{c}+ \text { isotretinoin, valproic acid } \rightarrow \text { increase } \\
\text { drug effect }\end{array}$ \\
\hline $\begin{array}{c}\beta \text {-caroten } \\
\text { (provitamin A) } \\
{[49]}\end{array}$ & inhibits proliferation of cells & $\begin{array}{l}\text { yellowish skin tinge, slight } \\
\text { diarrhoea }\end{array}$ & $\begin{array}{c}+ \text { simvastatin, niacin } \rightarrow \text { decreases drugs } \\
\text { effect }\end{array}$ \\
\hline $\begin{array}{c}\text { Vitamin E } \\
(\alpha \text {-tocopherol) } \\
{[7,49,58]}\end{array}$ & $\begin{array}{l}\text { stimulation of fertility, } \\
\text { activation of immune } \\
\text { system }\end{array}$ & $\begin{array}{l}\text { gastric pain, vomiting and } \\
\text { diarrhoea, muscular weakness, } \\
\text { rashes, skin inflammations }\end{array}$ & $\begin{array}{c}+ \text { oral anticoagulants, oestrogens } \rightarrow \\
\text { bleedings } \\
+ \text { antidiabetics } \rightarrow \text { hypoglycaemia }\end{array}$ \\
\hline
\end{tabular}


The nutrivigilance activity

In US, the herbal products are marked as dietary supplements or botanicals. The law covers aspects regarding the reporting of adverse events to FDA MedWatch scheme, by consumers, manufacturers, distributors, pharmacists etc. [51]. In EU, some herbal products can be included on the drugs list, requiring safety and quality standards, and having the obligation to report adverse events. Unlike drugs, DS authorization does not require any safety studies (preclinical, clinical or toxicological). The European legislation (including the Romanian legislation) refers only to their processing, preparing, authorising, trading, advertising and labelling.

In 2012, Palet et al., proposed that the adverse events' reporting system must be strongly encouraged all over the world [44]. This system represents the first main step for developing a new domain, Nutrivigilance, which is defined as "the science and activities relating to the detection, assessment, understanding and prevention of adverse events related to the use of a food, dietary supplement, or medical food" [51]. The term "nutrivigilance" is not used within the DS legislation framework, except in France, where Agence Nationale de sécurité sanitaire de l'alimentation, de l'environnement et du travail (ANSES) has been working since 2009 on this field, seeking to identify the adverse events of consuming DS [2,61]. Over the last few years, the European Food-Safety Authority's Advisory Forum has been trying to create a nutrivigilance network, following France's example. At the moment, many EU countries agreed to discuss the issue with ANSES [61]. Concretely, the Czech Republic has started too, the nutrivigilance activity in 2015 at the Centre for Health, Nutrition and Food in Brno. Several solutions to improving DS safe use have been identified by Cohen: a) reforming the legislation; b) founding centres to monitor DS adverse events; c) creating a database of all DS adverse events; d) requiring rigorous quality-control tests in order to authorize DS etc. [8]. The evaluation of intake risks can be achieved employing some models used for drugs, but adapted to DS: WHO scale, FDA algorithm, the Narnajo scale, Kramer scale or Liverpool scale [4, 19, 52, 53]. Ide et al. have adapted the FDA algorithm to estimate a causality relationship between adverse events and DS usage [27].

Because of its importance to people's life, nutrivigilance had been sustained by authorities. For example, in US, FDA together with the National Health Institute and The Dietary Supplements Office are continually financing research in this field in order to extend the scientific knowledge regarding DS efficacy and safety (more than 855 million USD during 2009 - 2011) [23, 24, 58]. Most of these funds were directed to projects for studying plants $(22 \%)$, vitamins $(20 \%)$, lipids (14\%), minerals and trace elements
$(10 \%)$. The targeted research fields were oncology, cardiology, and women's reproductive health [24].

\section{Conclusions}

This study presents some aspects that encourage the development of nutrivigilance as a main activity in the dietary supplements field. Its main object is "to detect, assess, understand or prevent the adverse events of food, dietary supplements or medical foods". In EU, including Romania, there are some regulations regarding dietary supplements which have been changed and improved during the time. However, these don't refer to the detecting, monitoring or collecting the dietary supplements adverse reactions. Taking into account of these aspects, the Romanian authorities should start the activity of nutrivigilance, following the example other countries. Thus, a major decrease in the risks related to dietary supplement adverse-events can be achieved with a better involvement of the pharmacists.

\section{References}

1. Agbabiaka TB, Wider B, Watson LK, Goodman C, Concurrent use of prescription drugs and herbal medicinal products in older adults: A systematic review. Drugs \& Aging, 2017; 34(12): 891-905.

2. ANSES, Dispositif national de nutrivigilance, www.anses.fr.

3. Asher GN, Corbett AH, Hawke RL, Common herbal dietary supplement-drug interactions. AFP, 2017; 96(2): 101-107.

4. Avigan MI, Mozersky RP, Seeff LB, Scientific and regulatory perspectives in herbal and dietary supplement associated hepatotoxicity in the United States. Int $J$ Mol Sci., 2016; 17(3): 331-360.

5. Basch E, Gabardi S, Ulbricht C, Bitter melon (Momordica charantia): A review of efficacy and safety. Am J Health Syst Pharm., 2003; 60(4): 356359.

6. Borghini C, Cicero AF, Nutraceuticals with a clinically detectable blood pressure-lowering effect: a review of available randomized clinical trials and their metaanalyses. Br J Clin Pharmacol., 2017; 83(1): 163-171.

7. Boullata J, Natural health product interactions with medication. Nutr Clin Pract., 2005; 20(1): 33-51.

8. Cohen PA, Hazards of hindsight - Monitoring the safety of nutritional supplements. $N$ Engl J Med., 2014; 370(14): 1277-1280.

9. Constantinesco LJ, Comparative law treaty, Vol. 2, Comparative Method, Ed. All Bucureşti, 1998, 4-39, 52-109, (available in Romanian).

10. Crişan $\mathrm{O}$, Good pharmacy practice in the context of cross-border healthcare. Farmacia, 2017; 65(2): 138-142.

11. Cuc Hepcal I, Toma CC, Olah N, Dehelean C, Motoc A, Ardelean S, Conea S, Morgovan C, Study of the oral contraceptives' use by women from Western Romania. Farmacia, 2015; 63(4): 310-316. 
12. de Boer A, van Hunsel F, Bast A, Adverse fooddrug interactions. Regul Toxicol Pharmacol., 2015; 73(3): 859-865.

13. Dennehy CE, Tsourounis C, Horn AJ, Dietary supplement-related adverse events reported to the California Poison Control System. Am J Health Syst Pharm., 2005; 62(14): 1476-1482.

14. Diaconu C, Vlase L, Cuciureanu M, Filip L, Assessment of flavonoids content in citrus juices using a LC/MS method. Farmacia, 2017; 65(1): 92-96.

15. Directive 2002/46/EC of the European Parliament and of the Council of 10 June 2002 on the approximation of the laws of the Member States relating to food supplements. Official Journal of the European Communities, L 183/12.07.2002.

16. Directive $2008 / 100 / \mathrm{EC}$ of 28 October 2008 amending Council Directive 90/496/EEC on nutrition labelling for foodstuffs as regards recommended daily allowances, energy conversion factors and definitions. Official Journal of the European Communities, L 285/29.10.2008

17. El Baza F, Al Shahawi HA, Zahra S, AbdelHakim RA, Magnesium supplementation in children with attention deficit hyperactivity disorder. Egypt $J$ Med Hum Genet., 2016; 17(1): 63-70.

18. European Advisory Services, The use of substances with nutritional or physiological effect other than vitamins and minerals in food supplements, Study undertaken for DG Sanco, European Commission, 2007, https://ec.europa.eu.

19. Garcia-Cazarin ML, Wambogo EA, Regan KS, Davis $\mathrm{CD}$, Dietary supplement research portfolio at the NIH, 2009-2011. J Nutr., 2014; 144(4): 414-418.

20. Ghibu S, Decea N, Morgovan C, Mogoşan C, An experimental model to induce metabolic syndrome in rats. The fructose - enriched diet. Farmacia, 2013; 61(2): 420-426.

21. Gruenwald J, Brendler T, Jaenicke C, PDR for Herbal Medicines, $3^{\text {rd }}$ edition, Thomson-PDR, 2004.

22. Halat KM, Dennehy CE, Botanicals and dietary supplements in diabetic peripheral neuropathy. $J$ Am Board Fam Pract., 2003; 16(1): 47-57.

23. Haller C, Kearney T, Bent S, Ko R, Benowitz N, Olson K, Dietary supplement adverse events: report of a one-year poison center surveillance project. $J$ Med Toxicol., 2008; 4(2): 84-92.

24. Halsad $\mathrm{CH}$, Dietary supplements and functional foods: 2 sides of a coin?. Am J Clin Nutr., 2003; 77(4): 1001-1007.

25. Heinrich M, Chan J, Wanke S, Neinhuis C, Local uses of Aristolochia species and content of nephrotoxic aristolochic acid 1 and 2 - A global assessment based on bibliographic sources. $J$ Ethnopharmacol., 2009; 125(1): 108-144.

26. Government Decision no. 590/2018 for establishing institutional rules and some measures to apply the Regulation (EU) 2015/2283 of the European Parliament and of the Council of 25 November 2015 on novel foods, amending Regulation (EU) No 1169/2011 of the European Parliament and of the Council and repealing Regulation (EC) No 258/97 of the European Parliament and of the Council and Commission Regulation (EC) No 1852/2001 and Commission Implementing Regulation (EU) 2018/456 of 19 March 2018 on the procedural steps of the consultation process for determination of novel food status in accordance with Regulation (EU) 2015/2283 of the European Parliament and of the Council on novel foods. Official Journal of Romania, part I, no 699/2018 (available in Romanian).

27. Ide K, Yamada H, Kitagawa M, Kawasaki Y, Buno Y, Matsushita K, Kaji M, Fujimoto K, Waki M, Nakashima M, Umegaki K, Methods for estimating causal relationships of adverse events with dietary supplements. BMJ Open, 2015; 5: 1-6.

28. Juncan AM, Rus LL, Influence of packaging and stability test assessment of an anti-aging cosmetic cream. Mater Plast., 2018; 55(3): 426-430.

29. Larzelere MM, Campbell JS, Robertson M, Complementary and alternative medicine usage for behavioral health indications. Prim Care, 2010; 37(2): 213-236.

30. Law no. 491 of $18^{\text {th }}$ November 2003 on medicinal and aromatic herbs and hive products republished. Official Journal of Romania, part I, no. 52/2011 (available in Romanian).

31. Manayi A, Vazirian M, Saeidnia S, Echinacea purpurea: Pharmacology, phytochemistry and analysis methods. Pharmacogn Rev., 2015; 9(17): 63-72.

32. Mathews N, Prohibited contaminants in dietary supplements. Sports Health, 2018; 10(1): 19-30.

33. Mawarti H, Rajin M, Asumta Z, The effects of Aloe vera on TNF-a levels, the percentage of Nk cells and Th 17 cells in rat that received izoniazid and rifampycin. Med Arch., 2017; 71(5): 308-311.

34. Minda D, Zinuca Pavel I, Borcan F, Coricovac D, Pinzaru I, Andrica F, Morgovan C, Nita LD, Soica C, Muntean D, Toma CC, Beneficial effects of a lupeol-cyclodextrin complex in a murine model of photochemical skin carcinoma. Rev Chim (Bucharest), 2015; 66(3): 373-376.

35. Morgovan C, Cosma S, Burta C, Ghibu S, Polinicencu C, Vasilescu D, Measures to reduce the effects of the economic and financial crisis in pharmaceutical companies. Farmacia, 2010; 58(4): 400-407.

36. Morgovan C, Cosma S, Ghibu S, Burta C, Bota M, Polinicencu C, Study of diabetes mellitus care cost in Romania during 2000-2008. Fundam Clin Pharmacol., 2010; 24(1): 92.

37. National Audiovisual Council, Press release, 18 October 2013, http://www.cna.ro.

38. Nicoteri JA, Food-drug interactions: Putting evidence into practice. Nurse Pract., 2016; 41(2): 1-7.

39. Olah NK, Osser G, Câmpean RF, Furtuna FR, Benedec D, Filip L, Raita O, Hanganu D, The study of polyphenolic compounds profile of some Rosmarinus officinalis L. extracts. Pak J Pharm Sci., 2016; $29(6$ Suppl): 2355-2361.

40. Order of Ministry of Health and Ministry of Agriculture, Forests and Rural Development no. 401/244/2005 for regulate the preparation and marketing of the medicinal and aromatic plants use as such or in food supplements. Official Journal of Romania, part I, no. 456/2005, (available in Romanian).

41. Order of the Minister of Agriculture, of the President of the National Sanitary Veterinary and Food Safety Authority and of the Minister of Health no. 1228/ $2005 / 63 / 244 / 2006$ for the approval of the technical 
norms on the marketing of pre-dosed food supplements of animal and plant origin and/or their mixtures with vitamins, minerals and other nutrients. Official Journal of Romania, part I, no. 253/2006, (available in Romanian).

42. Order of the Minister of Health no. 1069/2007 for the approval of the norms on food supplements. Official Journal of Romania, part I, no. 455/2007, (available in Romanian).

43. Order of the Minister of Agriculture and Rural Development no. 1946/2014 for the approval of the procedure for the notification of finished medicinal products, herbs and honey products, notified by the operators in the field, and which are classified as food supplements, products for internal or external use, excluding cosmetic products. Official Journal of Romania, part I, no. 950/2014

44. Palet DM, Low WL, Tan LL, Zhang Q, Low MY, Chan CL, Koh HL, Adverse events associated with the use of complementary medicine and health supplements: an analysis of reports in the Singapore Pharmacovigilance database from 1998 to 2009. Clin Toxicol (Phila.), 2012; 50(6): 481-489.

45. Patel SS, Beer S, Kearney DL, Phillips G, Carter BA, Green tea extract: a potential cause of acute liver failure. World J Gastroenterol., 2013; 19(31): 5174-5177.

46. Regulation no. 1924/2006 of the European Parliament and of the Council of 20 December 2006 on nutrition and health claims made on foods, Corrigenda. Official Journal of the European Union, L 12/18.01.2007.

47. Regulation (EC) No 1170/2009 of 30 November 2009 amending Directive 2002/46/EC of the European Parliament and of Council and Regulation (EC) No 1925/2006 of the European Parliament and of the Council as regards the lists of vitamin and minerals and their forms that can be added to foods, including food supplements. Official Journal of the European Union, L 314/01.12.2009.

48. Regulation (EU) no 432/2012 of 16 May 2012 establishing a list of permitted health claims made on foods, other than those referring to the reduction of disease risk and to children's development and health. Official Journal of the European Union, L 136/25.05.2012.

49. Rutkowski M, Grzegorczyk K, Adverse effects of antioxidative vitamins. Int $J$ Occup Med Environ Health, 2012; 25(2): 105-121.

50. Sanaei M, Banasiri M, Shafiee G, Rostami M, Alizad S, Ebrahimi M, Larijani B, Heshmat R, Calcium vitamin D3 supplementation in clinical practice: side effect and satisfaction. J Diabetes Metab Disord., 2016; 15(9): 1-3.

51. Schmitz SM, Lopez HL, MacKay D, Nutravigilance: principles and practices to enhance adverse event reporting in the dietary supplement and natural products industry. Int J Food Sci Nutr., 2014; 65(2): 129-134.

52. Shaw D, Ladds G, Duez P, Williamson E, Chan K, Pharmacovigilance of herbal medicine. $J$ Ethnopharmacol., 2012; 140(3): 513-518.

53. Shaw D, Toxicological risks of Chinese herbs. Planta Med., 2010; 76(17): 2012-2018.

54. Stickel F, Shouval D, Hepatotoxicity of herbal and dietary supplements: an update. Arch Toxicol., 2015; 89(6): 851-865.

55. Tamayo C, Diamond S, Review of clinical trials evaluating safety and efficacy of Milk Thistle (Silybum marianum [L.] Gaertn.). Integr Cancer Ther., 2007; 6(2): 146-157.

56. Teichner W, Lesko M, Cashing in on the booming market for dietary supplements, Consumer and Shopper Insights December 2013, www.mckinsey.com.

57. The United States Congress, Dietary Supplement Health and Education act of 1994, www.gpo.gov.

58. Timbo BB, Ross MP, McCarthy PV, Dietary supplements in a national survey: prevalence of use and reports of adverse events. J Am Diet Assoc., 2006; 106(12): 1966-1974.

59. Tiţa B, Morgovan C, Tita D, Neag TA, Antiinflammatory drugs interacting with $\mathrm{Zn}$ (II) metal ion synthesis, characterization and thermal behaviour of the complex with ketoprofen. Rev Chim. (Bucharest), 2016; 67(1): 38-41.

60. Vergari F, Tibuzzi A, Basile G, An overview of the functional food market: from marketing issues and commercial players to future demand from life in space. Adv Exp Med Biol., 2010; 698: 308-321.

61. Vujic M, Pollak L, Composition, labelling, and safety of food supplements based on bee products in the legislative framework of the European Union Croatian experiences. Arh Hig Rada Toksikol., 2015; 66(4): 243-249.

62. World Health Organization, The top 10 causes of death, http://www.who.int.

63. Wink M, Mode of action and toxicology of plant toxins and poisonous plants. Mitt Julius Kühn-Inst., 2009, 421: 93-112

64. *** Value of the dietary supplements market in Europe 2015 and 2020, by country, available at www.statista.com. 